\title{
Nāyika-Bheda in Ramayana
}

\author{
Rashmi H.L ${ }^{1}$, Dr. Choodamani Nandagopal ${ }^{2}$ \\ ${ }^{1}$ (M.Phil Scholar, Jain University, Bangalore, India) \\ ${ }^{2}$ (Dean, Faculty of Humanities and Social Sciences, Jain University, Bangalore, India)
}

\begin{abstract}
Indian epics are held in high esteem and revered as a sacred text. Ramayana and Mahabharata belong to this genre. Ramayana is regarded as the 'mahākāvya' written by the Ādikavi Valmiki. Though it refers to the story of Rama, the characters and emotions expressed takes the story of Ramayana to great heights. It is an emotive story which has in it all the nine rasas along with bhāvas, vibhāvas and anubhāvas. The sentiments and emotions behind the portrayal of a character can be better understood with help of performing arts like music, drama or dance, as they convey the expressions more effectively.

Female characters have always been regarded important in any literary text. Bharata in Nätyashästra, refers to these important women characters as "Näyika". Each character expresses a strong personality and nature which changes emotionally depending on the situations. These kinds of changes give ample scope to study various individuals with reference to characteristics of 'nayyikas'. The women characters in Ramayana(from the central character of Sita to the other peripheral characters) are all integral part of the entire narration. This paper titled 'Näyika-bheda in Ramayana' is a study on the portrayal of Nāyika-bhedas according to Nātyashāstra, with reference to women characters of Ramayana.
\end{abstract}

Keywords: Ramayana, Nāyika-bheda, Nātyashāstra, women characters, dance, performing arts

\section{Introduction:}

Ramayana is an epic so widely popular amongst the people that it has influenced the people in all aspects of their daily life. Ramayana is not just history, but a part of Hindu mythology. The great qualities of the hero, heroine and other characters have been deeply rooted in the minds of the people. This epic is undoubtedly one of the greatest treasures of literature and has been seen as a significant text from ancient times to modern days, thus making it immortal. Ramayana has 24,000 ślokas in it and has a specific meter which the poet Valmiki himself discovered. Valmiki says that Sri Rama was God, but limited himself and came down amongst men to function for a cause in order to bring peace and order, by putting an end to the sufferings of humans at the hands of evi ${ }^{[1]}$. The text not only covers poetry but also gives information about rhetoric, medicine, geology, geography, botany and every facet of civilization. Ramayana is unique and well-known because of its long continuity of storyline and for the interpretation and portrayal of characters. The power and influence of such text in the social life of people is such that the names of the characters have been in circulation since time immemorial ${ }^{[2]}$.It is a story with hidden meaning wherein Rama and Ravana symbolize the good and evil. The kindness and righteousness are being countered by jealousy, lust, ego and hunger for power. The epic poem of India narrates the journey of Rama and Sita who were deeply in love with each other.

\section{Emotive Elements In Ramayana:}

The characters in the epic experience these sentiments very often. Karunarasa being the foremost, it flows throughout the story. Veera and raudrarasa take the second place. The emotive element of the epic gives rise to the classification of characters. The men characters like Rama and Ravana adorn the dheerodata and dheeroddatanayakas respectively.The main aim of any art is to evoke the rasa in the mind of the onlooker. Through movements, the artist creates the rasa and conveys it to the audience in order to create mood. In the Ramayana period, we can see glimpses of dance and music. While reciting the stories the reciters also added the element of abhinaya. The nine rasas which arise in the episodes of Ramayana makes it more expressive. Śringārarasa is delicately intertwined between Rama and Sita, veerarasa is expressed when Rama breaks Shiva's bow, hāsyarasa evokes with Shoorpanaka's acts, bhayannaka can be felt with the abduction of Sita, karunarasa flows throughout the story right from Dasharatha's lamentation for Rama until Sita's sanctity is tested by fire. Adbhutarasa can be seen with the construction of the gigantic bridge of stones by the monkeys. Rama confronts Ravana in the battle field exhibiting raudrarasa. Bhibatsarasa can be seen in the after effects of the war, where dead bodies of many humans, rākhshasās and monkeys are seen in the battlefield ${ }^{[3]}$. With the performing arts such as dance, many of these emotions expressed can be understood by the audience in a better way. 
Dance is a means of communication and a personal expression of joy transcending all barriers. Dance created through rhythmic movements evokes the feelings of bliss in a spiritual way. Indian dance synthesizes the techniques of many other arts to evolve as an art form on its own which is considered to be, the most significant of all, as it represents the unceasing rhythm of the cosmos ${ }^{[4]}$. Even in Nātyashāstra it is referred that dance represents the nature of society and the moods in the world (Bharata, 'Nātyashāstra', Chapter 1, śloka 119). Dance has its own technique, content, intent, skills and application. Each of these must be understood and applied so as to appreciate the intricacies of the art. Art creates the image. The value of art lies in the ability to objectify and convey the emotion. To objectifyan emotion is to remove it from its original experience and to evaluate it for its uniqueness. By means of art, an individual can aesthetically experience the emotion conveyed. In dance, emotions and meanings are expressed without involving as a person. The effects of creative effort and production are the final value of any creative art.

While speaking about the emotive elements that govern one's own life, the eminent writer on Valmiki Ramayana, Romesh C Dutt puts it as "Sorrow and suffering, trial and patience are a part of the Hindu ideal of a perfect life of honesty" ${ }^{5]}$.

Childlike innocence, the essence of integrity, righteousness, calmness, bravery, humility, love, compassion, obedience, commitment and human abilities, the aggressiveness, arrogance and short tempered nature, brotherly love, dedication, self-control, patience and sacrifice, jealousy and envious nature along with greed, valor and kind heartedness makes the story more interesting. The rich thematic and textual content in Ramayana theatre, has given great impetus to its representation through dance, drama and music.

All classical dances reflect the story of Ramayana in the form of dance-dramas or ballet or as a theme. The characters depicted through dance gives a wide scope for understanding of the characters and their emotions in a better way.

\section{NāyikaBheda According To Nātyashāstra:}

Bharata in the $25^{\text {th }}$ chapter on generic representations gives importance to the sattva (internal emotion). He categorizes the emotions also into three qualities, namely superior, middle and inferior. The representations of the emotions is rather vague in nature since it is dependent on the mental feeling and it becomes evident as a sentiment with the features of horripilation, tears, etc., produced at the right moment (Nätyashasstra, 639). Different treatises after Nātyashāstra deal with the nāyikabhāva by classifying them differently.

\section{Classification Of Nāyikas:}

"Drama or dance represents the nature of society and the moods in the world. Because of the vast variety of human beings, the actor or dancer should understand the complexity of characters or their moods that he or she portrays." This is one of the reasons as to why treatises either of dramatology or literature deal in detail with the classification of various characters. Bharata gives a universal classification of all men and women - uttama, madhyama and adhama ${ }^{[6]}$. The hero is called nayyaka and the heroine of the play is called the nāyika.

Bharata refers to woman as the root cause of all happiness or sorrow and recommends that treatment given to her should be graceful. He classifies the nāyikas based different factors. The classification has been made based on social status, aoristic sentiments, age, temperament, behavioral actions and modesty. He lists out the qualities of an ideal nāyika. He says that nayyika should be charming, virtuous, modest, pious and of good moral character. He characterizes the näyikas as youthful, fair, affectionate, pure, holy, sacred, noble, lovely, and combined with laya, tāla and rasa and possessing such other qualities. Nāyaka or nāyika, plot of the story and the rasa, form the basic necessary elements in any poetic composition. The nayika occupies more space than the hero in the literature of drama according to Schmidt. He says that "woman is a much more interesting and many sided object of study than man" ${ }^{[7]}$. Näyikashave been classified according to their age or experience, their physique and talent.Śringāra is the main sentiment which is dominated by love in separation ${ }^{[8]}$. Śringāra literature dates back to Bharata'sNätyashästra, and it deals with the emotions and sentiments in detail. The classifications of women are done based on their mood, sentiment and situation. The eightfold classification of heroines and the rules which govern their characteristics are also described. Different texts refer to the Nāyikas and their classification. Texts like SāhityaDarpana, Bhāshabhushana, Rasikapriya, Kāmasutra, Ratirahasya, Rasamanjari, etc., give ample scope for understanding the nature of nāyikas.

Nätyashāstra refers to ten stages of love that a dancer can portray in the treatment of anāyika in love. Bharata gives an eightfold classification of the nayyika. He gives a description of the behavior of nāyika in a particular situation. A dancer is expected to understand the nature of the nayyika to be portrayed in the right perspective. Emotions behind each nayyika can be artistically expressed by a dancer. Imagination of God as the lover himself leads to the different psychological states of the heroines. These states are personified as nāyikas, most of which are in relation to her beloved or lover.

Bharata gives a threefold classification commonly for nāyaka and nāyika, namely: Uttama, Madhyama and Adhama.According to Bharata,Divya, Nŕpastri, Kulastri and Ganika, arethe types of nāyikas based on social 
status all of the udattatemperament. Based on the manner of treatment by the kings, women have been specified to be of seventeen sub-classes, though they are not seen in the context of dance, but from the context of drama. These nāyikasexperience the love sicknessmentally and physically.

A woman who, without jealousy expresses her anger only when there is cause and who has adequate sense of priorities of work: is called Uttamanayyika.Madhyama is similar to uttama but in lesser degree. She is less dependable, inaccurate and wicked. One who has high self-esteem and ego and one who can be convinced easily is a madhyamanayika. A woman who gets angry on wrong occasions, who is doubtful, egoistic, very fickle minded, one whose anger and annoyance persist for a long time is called Adhama or Nichanāyika. Another kind of classification mentioned by Bharata is based on stages of youth, being Prathama, Dvitiya,Tritiya and ChaturthaYouvanāvasthas.Classification based on the social relationships are as follows:Svakiya (married, wife), Parakiya (married woman loving another man) and Sāmānya(courtesan). On the basis of age: Mugdhā, Madhya and Pragalbhā. Classifications based on the mental status and situations are as follows: Vāsakasajjā, Virahotkantitha, Kalahāntarita, Khandita, Vipralabdhāa, Proshitabhartrkā and Abhisārika.

\section{Portrayal Of NāyikaBheda In Ramayana:}

Characters in the epics are examples in which humanity is cast, and remain forever. Every story has embedded in it a philosophical or moral significance and an understanding of the distinction between good and evil $^{[9]}$. The characters of Ramayana are more often the ideals of devotion to truth and of womanly faithfulness and love in domestic life. The important female characters of Ramayana play a pivotal role to the plot and trigger the discussion on the variables of the emotive elements. Every ' $k \bar{a} n d a$ ' has a woman character that drives the story further and helps in making the narrative more interesting.

Valmiki was a sage, hence has not highlighted romantic sentiment to focus on the śringārarasa. Though we can see glimpses of it, more importance was given to the sentiment of karuna. The very basis of the epic stands on pathos.Śringārarasa being the king of rasas can be seen very often in the epic, but not in a significant manner. The relationships of the nāyikas with their nāyakas were more of devotion and duty than with the lust for love. Women portrayed in Valmiki Ramayana are more like, very obedient and loyal to their husbands. The concept of love represented in Ramayana appears to be the same as that in later Indian literature ${ }^{[10]}$. The feeling of love had been conceived as a god who was known as Manmatha, Käma, Ananga and Kandarpa. The aesthetic beauty of nature is explained very often to create the mood. The anubhavvas and vibhāvas play a very important role in creating the required rasa. The women characters of Ramayana have always been inspiring to many even today. Ramayana has a mention of more than hundred characters, of which,significant references can be made to only a few female characters. Some of these have uniqueness in their portrayal. Patience, love, devotion, sacrifice, selflessness are seen in the female characters which make them highly respectable in the society. Characterization done in the story could be related to the classifications done by Bharata in Nātyashāstra.

The women characters that portray the characteristics of different kinds of nāyikas are as follows:

Sita, Kausalya, Mandodari, Tara, Ahalya, Anasuya, Urmila, Sumitra who are all of the uttama characteristics. Sita, the daughter of Janaka is the central character of the story and plays an important role. She can be portrayed assvakiyanayika, a kulaja (of high birth)and divya kind of nāyika. She is an ideal woman who has tolerance, forgiveness, and self-respect, is looked upon as the highest preference. She is a pleasant blend of human emotions, intelligence and faithfulness. She can be regarded as the virahotkantithanayika.Kausalya, the queen wife of Dasharatha is a character who is also of the uttama kind representing the svakiyaclassification. She can be seen under the classification of Jyeshtanāyika. Her other qualities are mercy, generosity, equanimity, tolerance and patience. She is also under the fear of suspicion and wrath. She can be classified under the characteristics of vipralabdhanayika.Mandodari is regarded as the most beautiful, righteous, courageous and faithful wife of Ravana. Her character is matchless and included in the list of the five maidens. She can be classified under the uttamanāyika, being a praudhanayyika and resembling the characteristics of avipralabdhanayika. Tara wife of Vali, can be classified as uttamanāyika, she can be seen in the classification of a praudhanāyika who is a svakiyanāyika. Urmila, wife of Lakshmana can be classified under the uttamanäyika who is a soft natured lady with very high self-esteem. She is a mugdhanayika who is innocent of the worldly affairs but matured in taking the decisions.Her psychological status during the time of separation from Lakshmana can be compared to that of a virahotkantithanäyika, and her wait for him, can be stated as a proshitabhartrkanāyika.

Characters like Kaikeyi, Manthara,etc., who are wicked and undependable can be seen as the madhyamanāyikas. Kaikeyi can be classified under the swädhinapatikanāyika and khanditanayika. Ahalya being the wife of sage Gautama is deceived of her husband's love and gets the attention from Indra, who comes in disguise and satisfies her quest for love. She has also been regarded as one of the five maidens who are to be worshipped.She can be classified under the category of mugdhanāyika andas a vipralabdhanäyika. Ascetic 
characters do not fall into this category of nāyikabhāva.Shoorpanakha, Trijata and Tataka form the demon group, who do not have the nayyika-nāyaka relation and therefore their attraction towards men is only temporary which is on account of lust and not of love.

\section{Conclusion:}

The variety of roles played by the important characters of Ramayana give a wide range of nāyikabhavas. There are anumber of women characters in Ramayana but, the nāyika relation with their näyakacan be seen only with a few. The leading women characters having the relationship of husband and wife are taken for the study of nayikabheda. Women characters that are well known in the story are held high in their status because of their importance in each episodewhich takes the story to great heights. Each woman character has a unique characteristic which makes a person think about her in a different way. As we study the characters in detail, we observe them from different perspectives. To explore these women characters and the emotions behind themin the perspective of nāyikabheda,Näyashāstrahelps as an encyclopedia.Nātyashāstrabeing a text on dramaturgy gives enormous details regarding the nature and rules pertaining to the characterization of the hero and heroine. This classification, when applied to the characters of different literary texts give a totally different dimension to the story and perhaps creates a curiosity to explore some more characters and relate them to the preferred study. Thus, in order to know the literary works, their characters and their relevance and importance in the story, Nätyashāstragives manyimportant chapters which help us to understand the text in a better manner. It is left to the researcher to find the different aspects on which the study can be conducted.

\section{References:}

[1] V. S Srinivas Shastri, Lectures on Ramayana. (Chennai: Madras Samskrit Academy, 1961)

[2] ChoodamaniNandagopal, Textual and Contextual Dynamism in Ramayana Sculptures, Proc. CPR Conference,Chennai, C.P. R. Institute of Indological Research, 2013

[3] N RanganathaSharma, Sri RamakathaManjari(Bangalore: Ramayana Prakashana, 2000)

[4] KapilaVatsyayan, Indian Classical Dance (New Delhi: Publications Division, Ministry of I\&B, Govt. of India, 2007)

[5] Romesh C Dutt, The Valmiki Ramayana (New Delhi: Vijay Goel Publishers, 2010)

[6] PappuVenugopal Rao, Rasamanjari of Bhanudatta: An Insight into the Classification of Nayikas and Nayakas (Chennai: Pappu's Academic and Cultural Trust, 2011)

[7] Rakesh Gupta, Studies in Nayaka-Nayika-Bheda (New Delhi: Eastern Book Linkers, 2013)

[8] Frank Burch Brown(ed),Oxford Handbook f Religion and the Arts. (New York: Oxford University Press, 2014)

[9] R. K. Narayan,The Ramayana: A Shortened Modern Prose Version of the Indian Epic (New Delhi: Penguin Books, 2006)

[10] Ananda W. P Guruge, The Society of the Ramayana (New Delhi: Abhinav Publications, 1991) 